\title{
Finansowanie klubów sportowych z budżetu jednostek samorządu terytorialnego - sposoby wsparcia i studium interpretacji przepisów
}

Financing of sports clubs from the budget of local self-government units - ways to support and the study the interpretation of regulations

Streszczenie. $\mathrm{W}$ artykule scharakteryzowano alternatywne metody finansowania klubów sportowych. Przedstawiono pojęcie klubu sportowego, formy prawnoorganizacyjne oraz omówiono możliwości pozyskiwania środków finansowych. Podkreśla się fakt istotnego znaczenia środków, jakie otrzymują kluby sportowe $\mathrm{z}$ budżetów jednostek samorządu terytorialnego. W podsumowaniu przedstawiono wnioski, iż kluby sportowe odgrywają istotne role, a także to, że bez odpowiedniego wsparcia finansowego ze strony jednostek samorządów terytorialnych działalność tych klubów byłaby utrudniona.

Słowa kluczowe: klub sportowy; finansowanie sportu; budżet; samorząd terytorialny. 
Abstract. The article characterises alternative methods of financing sports clubs. The text also presents the concept of a sports club as well as legal and organizational forms. The possibilities of raising funds were also discussed. The article highlights an importance of resources obtained by sports clubs from budgets of local self-government units. The summary concludes that sports clubs play a significant role and that without an appropriate financial support from local government units, the activities of these clubs would be constricted.

Keywords: sports club; sports financing; budget; local government.

\section{Uwagi wstępne}

Finansowanie klubów sportowych z budżetu jednostek samorządu terytorialnego to duże wyzwanie, ale i ogromna odpowiedzialność. Nieodłącznym elementem rywalizacji sportowej są finanse, będące podstawą funkcjonowania każdego klubu sportowego. Brak odpowiedniego zabezpieczenia finansowego utrudnia klubom sportowym utrzymanie swego bytu, zwłaszcza tym znajdującym się w małych miastach czy wsiach. Możliwości skorzystania z finansowania z budżetu jednostek samorządu terytorialnego należy ocenić pozytywnie. W szczególności warto zwrócić uwagę, że kluby sportowe z małych miast i wsi mają bardziej ograniczone możliwości w pozyskiwaniu sponsorów zewnętrznych niż kluby z dużych miast $^{1}$. Dlatego też ustawodawca w dwóch ustawach, tj. ustawie o sporcie ${ }^{2}$ oraz ustawie o działalności pożytku publicznego i o wolontariacie ${ }^{3}$, wskazuje na mechanizmy takiego wsparcia finansowego z budżetu jednostek samorządu terytorialnego. W tym miejscu warto wskazać, że w Konstytucji RP w art. 68 ust. 5 postanowiono „Władze publiczne popierają rozwój

\footnotetext{
1 P. Chrzanowska, Rola dotacji celowych z budżetu gminy w kontekście rozwoju klubów sportowych w małych miejscowościach, „Zeszyty Naukowe Politechniki Częstochowskiej Zarządzanie” 2015, nr 20, s. 17.

2 Ustawa z dnia 25 czerwca 2010 r. o sporcie (tekst jedn. Dz.U. z 2016 r., poz. 176, dalej: u.s.).

3 Ustawa z dnia 24 kwietnia 2004 r. o działalności pożytku publicznego i o wolontariacie (tekst jedn. Dz.U. z 2016 r., poz. 1817, dalej: u.o.d.p.p.).
} 
kultury fizycznej, zwłaszcza wśród dzieci i młodzieży”4. Ponadto w myśl art. 27 ust. 1 u.s. zadaniem własnym jednostek samorządu terytorialnego jest „tworzenie warunków, w tym organizacyjnych, sprzyjających rozwojowi sportu”. Należy podzielić pogląd, że jest to zadanie o charakterze fakultatywnym, a nie obligatoryjnym ${ }^{5}$. Co więcej, art. 27 ust. 2 u.s. stanowi, że organ stanowiący jednostki samorządu terytorialnego może określić, w drodze uchwały, warunki i tryb finansowania zadania własnego, wskazując w uchwale cel publiczny z zakresu sportu, który jednostka ta zamierza osiągnąć. Jeśli chodzi o przepisy, które znajdują się w ustawie o działalności pożytku publicznego i o wolontariacie, warto pamiętać, że wsparcie finansowe mogą uzyskać kluby sportowe, które nie działają w celu osiągnięcia zysku (art. 3 ust. 2 pkt 4 u.o.d.p.p.).

Za udzielenie klubom sportowym dotacji odpowiada jednostka samorządu terytorialnego. To ona decyduje na podstawie jakiej ustawy klub może starać się o dotację. Na gruncie obowiązujących przepisów prawa istnieją dwie alternatywne metody wsparcia finansowego dla klubów sportowych. Ustawodawca pozostawia ten wybór samorządom.

\section{Pojęcie klubu sportowego}

Pojęcie klubu sportowego to pojęcie często używane i bardzo ważne. Powstaje pytanie, co należy rozumieć przez klub sportowy. W doktrynie można się spotkać z interpretacją, że „klub sportowy nie jest podmiotem prawa, to jedynie zwyczajowa nazwa pewnej organizacyjnej formuły dopuszczonej prawem”6. W myśl art. 3 u.s. działalność sportowa jest prowadzona w szczególności w formie klubu sportowego, który funkcjonuje jako osoba prawna. W związku z tym pojawia się pytanie, w jakiej formie prawnej może działać klub sportowy? Istotnie należy wskazać, że ustawo-

4 Konstytucja Rzeczypospolitej Polskiej z dnia 2 kwietnia 1997 r. (Dz.U. 1997 r., Nr 78, poz. 483 ze zm.).

5 M. Obrębalski, Wspieranie rozwoju sportu jako zadanie jednostek samorzq̨u terytorialnego, [w:] A. Babczuk, A. Talik (red.), Finansowanie sportu ze środków publicznych, Warszawa 2014, s. 4.

6 Zob. np. D. Dudek, Pojęcie klubu sportowego, „Studia Humanistyczne” 2005, nr 5, s. 26. 
dawca nie wprowadza ograniczeń co do formy prawnej. W tym miejscu warto wskazać, że klub sportowy jest prowadzony w wielu formach prawnych, do których zalicza się spółki kapitałowe, tj. spółki z ograniczoną odpowiedzialnością lub spółki akcyjne, zarówno te na gruncie Kodeksu spółek handlowych z dnia 15 września 2000 r. nastawione na osiągnięcie $z$ zsku$^{7}$, jak i te na gruncie ustawy o działalności pożytku publicznego i o wolontariacie, niedziałające dla zysku i przeznaczające całość dochodu na realizację celów statutowych (art. 3 ust. 2 pkt 4 u.o.d.p.p.). Te ostatnie są beneficjentami dotacji z jednostek samorządu terytorialnego. Ponadto do katalogu osób prawnych zalicza się stowarzyszenia, fundacje oraz spółdzielnie ${ }^{8}$. Jeśli chodzi o te ostatnie, to należy podkreślić, że nie będą one beneficjentami środków z jednostek samorządu terytorialnego, ponieważ w ich ustrój wpisany jest cel zarobkowy, co wyklucza dotację ${ }^{9}$.

Nadmienić jednak należy, że istnieje również uczniowski klub sportowy, który zgodnie z art. 4 u.s. jest „szczególnym rodzajem klubu sportowego”. Funkcjonuje on w oparciu o przepisy ustawy z dnia 7 kwietnia 1989 r. - Prawo o stowarzyszeniach ${ }^{10}$, z wyłączeniem przepisów dotyczących rejestracji. W praktyce jest to klub sportowy, który nie może prowadzić działalności gospodarczej ${ }^{11}$. Jego celem jest działalność sportowa, a wszelkie próby podejmowania działalności gospodarczej uznaje się, jako sprzeczne z prawem, za nieważne ${ }^{12}$.

Kodeks spółek handlowych z dnia 15 września 2000 r. (tekst jedn. Dz.U. z 2016 r., poz. 1578).

W. Cajsel, Ustawa o sporcie. Komentarz, Warszawa 2011, s. 45-49.

Tamże, s. 48.

10 Ustawa z dnia 7 kwietnia 1989 r. Prawo o stowarzyszeniach (tekst jedn. Dz.U. z 2017 r., poz. 210).

11 A. Rejman, Uczniowskie kluby sportowe w Polsce w świetle obowiq̨zujqcych uregulowań prawnych oraz orzecznictwa sq̨dów powszechnych, „Quality In Sport” 2015, nr 4, s. 58.

12 Postanowienie Sądu Okręgowego w Toruniu z dnia 2 kwietnia 2013 r., VI Gz 44/13, Legalis nr 734942. 


\section{Model wsparcia finansowego klubu sportowego na podstawie ustawy o sporcie}

Punktem wyjścia dla analizowanej problematyki są artykuły 27 i 28 u.s. Jak już wcześniej wspomniano, art. 27 u.s. formułuje zadanie własne jednostek samorządu terytorialnego polegające na „tworzeniu warunków, w tym organizacyjnych, sprzyjających rozwojowi sportu”. Istotne znaczenie ma jednak ustęp 2 tego przepisu, który stanowi, że „Organ stanowiący jednostki samorządu terytorialnego może określić, w drodze uchwały, warunki i tryb finansowania powyższego zadania własnego, wskazując w uchwale cel publiczny z zakresu sportu, który jednostka ta zamierza osiągnąć”. Co więcej, wyżej wymienione przepisy ustawy nie naruszają uprawnień jednostek samorządu terytorialnego do wspierania kultury fizycznej na podstawie przepisów odrębnych. W ten sposób rady gmin, powiatów czy sejmiki wojewódzkie mogą również stosować inne ustawy wspierających kulturę fizyczną, w której mieści się także sport ${ }^{13}$, m.in. przepisy z art. 11-19a u.o.d.p.p. Należy stwierdzić, że przyznanie dotacji klubowi sportowemu wymaga ustalenia celu publicznego z zakresu sportu w uchwale określającej warunki i tryb finansowania takiego zadania własnego i udzielenia tej dotacji. W tym miejscu warto wyjaśnić znaczenie celu publicznego, jaki zamierza zrealizować dana jednostka samorządu terytorialnego, przez który należy rozumieć każdorazowo poprawę warunków uprawiania sportu przez członków klubu sportowego lub zwiększenie dostępności społeczności lokalnych do działalności sportowej prowadzonej przez klub sportowy ${ }^{14}$. Ponadto trzeba podzielić pogląd, że cel publiczny wymaga konkretyzacji, a nie ogólnego ujęcia ${ }^{15}$. W doktrynie wymienia się następujące przykłady celu publicznego: zapewnienie warunków niezbędnych do występów w określonej klasie rozgrywkowej lub zdobycie pozycji medalowych na danych imprezach, zapewnienie warunków niezbędnych do osiągania wysokich wyników sportowych przez za-

13 B. Wankiewicz, Wpływ sportu na rozwój lokalny w świetle ustawy o sporcie, „Zeszyty Naukowe Uniwersytetu Szczecińskiego" 2011, nr 690, s. 423-424.

14 Tamże, s. 425.

15 J. Kosowski, Finansowanie klubów sportowych na podstawie ustawy z 25.06.2010 r. o sporcie, „Samorząd Terytorialny” 2012, nr 7-8, s. 154. 
wodników klubów sportowych, poprawa warunków uprawiania sportu, zwiększanie dostępności mieszkańców do działalności sportowej lub obiektów sportowych, propagowanie postawy fair play poprzez kibicowanie lub czynny udział mieszkańców w zawodach sportowych, zaspokajanie potrzeb społecznych poprzez integrowanie się kibiców, zwiększanie dostępności mieszkańców do działalności sportowej, pobudzanie inicjatyw społecznych w zakresie organizacji (nowych) imprez sportowych, promocja sportu wśród mieszkańców ${ }^{16}$.

Wskazówką może być również uchwała Rady Gminy Człuchów, która za cel publiczny z zakresu sportu uznała m.in. „upowszechnianie kultury fizycznej poprzez wspieranie rozwoju sportu, wychowania fizycznego, rehabilitacji ruchowej oraz innych form zorganizowanych i niezorganizowanych aktywności fizycznej, które przez uczestnictwo doraźne lub zorganizowane wpływają na wypracowanie lub poprawienie kondycji fizycznej i psychicznej, rozwój stosunków społecznych lub osiągnięcie wyników sportowych na wszelkich poziomach”" ${ }^{\text {. }}$.

Z kolei w uchwale Rady Gminy Czerwonak cel publiczny z zakresu sportu obejmuje takie kwestie jak: poprawianie warunków uprawiania sportu na terenie gminy przez zawodników klubów sportowych, w tym w szczególności przez dzieci i młodzież z terenu gminy, upowszechnianie i krzewienie sportu na terenie gminy, promowanie sportu i aktywnego stylu życia, zwiększenie dostępności społeczności lokalnej, w tym w szczególności dzieci i młodzieży z terenu gminy do uprawiania spor$\mathrm{tu}^{18}$. Wyraźne określenie celu publicznego może zapobiec w przyszłości problemom z prawidłowym rozliczeniem dotacji. Dlatego też warto na etapie podejmowania uchwały precyzyjnie określić cel publiczny z zakresu sportu.

16 Tamże, s. 154-155.

17 Uchwała nr LVII/403/10 Rady Gminy Człuchów z dnia 10 listopada 2010 r. w sprawie określenia warunków i trybu finansowego wspierania rozwoju sportu w Gminie Człuchów, http://www.gdansk.uw.gov.pl/du/2011/Nr_03_z_dnia_11.01.2011r.pdf (dostęp: 11.03.2017 r.).

18 Uchwała nr 181/XIX/2016 Rady Gminy Czerwonak z dnia 24 marca 2016 r. w sprawie określenia warunków i trybu finansowania wspierania rozwoju sportu w gminie Czerwonak http://bip.czerwonak.pl/public/get_file_contents.php?id=260527 (dostęp: 11.03.2017 r.). 
Na podstawie art. 28 u.s. klub sportowy, prowadzący swoją działalność na obszarze danej jednostki samorządu terytorialnego, niedziałający na osiągnięcie zysku może otrzymywać dotację celową z budżetu tej jednostki. Przyjąć należy, iż dotację celową w tym wypadku mogą otrzymać wyłącznie kluby sportowe nieprowadzące działalności nakierowanej na zysk finansowy. Chodzi tutaj o te formy prawne wymienione w charakterystyce pojęcia klubu sportowego. Ponadto do wyżej wspomnianego artykułu mają zastosowanie również przepisy z ustawy z dnia 27 sierpnia 2009 r. o finansach publicznych ${ }^{19}$ w zakresie udzielania dotacji celowych dla podmiotów niezaliczanych do sektora finansów publicznych i niedziałających w celu osiągnięcia zysku (art. 220 u.f.p.).

Warto zasygnalizować, że w wyżej przytoczonym przepisie podstawą udzielonej dotacji jest umowa zawarta pomiędzy jednostką samorządu terytorialnego a klubem sportowym. Ponadto w umowie należy dość szczegółowo określić opis zadania, w tym cel, na jaki dotacja została przyznana $^{20}$.

Konkludując powyższe rozważania, można wysunąć wniosek, że klub sportowy, aby ubiegać się o dotację celową, spełnić musi dwa konieczne warunki:

1. prowadzić działalność na obszarze danej jednostki samorządu terytorialnego oraz

2. nie prowadzić działalności w celu osiągnięcia zysku.

W art. 28 ust. 2 u.s. postanowiono, że dotacja celowa pochodząca z budżetu jednostki może być przeznaczona na: realizację programów szkolenia sportowego, zakup sprzętu sportowego, pokrycie kosztów organizowania zawodów sportowych lub uczestnictwa tych zawodach, pokrycie kosztów korzystania z obiektów sportowych dla celów szkolenia sportowego, sfinansowanie stypendiów sportowych i wynagrodzenia kadry szkoleniowej.

19 Ustawa z dnia 27 sierpnia 2009 r. o finansach publicznych (tekst jedn. Dz.U. z 2016 r., poz. 1870, dalej: u.f.p.).

20 W. Lachiewicz, Uchwała o dotacjach z budżetu jednostki samorzqdu terytorialnego na cele publiczne z zakresu rozwoju sportu, [w:] P. Walczak (red.), Uchwały i zarzqdzenia organów samorzq̨du terytorialnego dotyczq̨ce spraw finansowych, Warszawa 2016, s. 182-183. 
Nadmienić jednak trzeba, że konieczne jest, by udzielona dotacja wpływała na poprawę warunków uprawiania sportu przez członków klubu sportowego, który otrzyma dotację, lub zwiększała dostępność społeczności lokalnej do działalności sportowej prowadzonej przez ten klub. W związku z tym powyższy sposób wsparcia finansowego klubów sportowych uznaje się za dodatkowy model dofinansowania klubów sportowych przez jednostki samorządu terytorialnego ${ }^{21}$.

\section{Model wsparcia finansowego klubu sportowego na podstawie ustawy o działalności pożytku publicznego i o wolontariacie}

Drugi sposób wsparcia finansowego klubów sportowych dostępny jest w oparciu o ustawę o działalności pożytku publicznego i o wolontariacie. W myśl art. 3 ust. 1 u.o.d.p.p. działalność pożytku publicznego określona jest jako działalność społecznie użyteczna, prowadzona przez organizacje pozarządowe w sferze zadań publicznych określonych w ustawie. Ustawodawca nie decyduje się jednak na ograniczenie tej działalności tylko do organizacji pozarządowych. Zgodnie z art. 3 ust. 3 u.o.d.p.p. „działalność pożytku publicznego może być prowadzona także przez (...) spółki akcyjne i spółki z ograniczoną odpowiedzialnością oraz kluby sportowe będące spółkami działającymi na podstawie przepisów ustawy z dnia 25 czerwca 2010 r. o sporcie, które nie działają w celu osiągnięcia zysku oraz przeznaczają całość dochodu na realizację celów statutowych oraz nie przeznaczają zysku do podziału między swoich udziałowców, akcjonariuszy i pracowników".

W związku z tym jednostki samorządu terytorialnego mogą na zasadach określonych w ustawie o działalności pożytku publicznego i o wolontariacie zlecać m.in. klubom sportowym realizację zadań publicznych w dwóch formach:

21 K. Sawicka, Podstawy prawne finansowania sportu z budżetu jednostek samorzqdu terytorialnego, [w:] A. Babczuk, A. Talik (red.), Finansowanie sportu ze środków publicznych, Warszawa 2014, s. 33. 
1. powierzenia wykonywania zadań publicznych wraz z udzieleniem dotacji na finansowanie ich realizacji,

2. wspierania wykonywania zadań publicznych wraz z udzieleniem dotacji na dofinansowanie ich realizacji (art. 5 ust. 4 pkt 1-2 u.o.d.p.p.). Różnica między powierzeniem a wspieraniem polega na tym, że „powierzenie wykonania zadania publicznego wymaga pełnego pokrycia kosztów jego realizacji, podczas gdy wspieranie wykonania takiego zadania wiąże się tylko z jego dofinansowaniem”22. W tym miejscu warto wskazać, że sfera zadań publicznych obejmuje zadanie, które określa się mianem „wspierania i upowszechniania kultury fizycznej” (art. 4 ust. 1 pkt 17 u.o.d.p.p.). Zgodnie z definicją legalną na gruncie u.s. w art. 2 kultura fizyczna obejmuje sport, wychowanie fizyczne oraz rehabilitację ruchową. Dlatego też zadanie publiczne w postaci „wspierania i upowszechniania kultury fizycznej” uznać należy za „potencjalny obszar działania klubu"23.

Jednostki samorządu terytorialnego na każdym szczeblu współpracują z klubami sportowymi, które spełniają określane wcześniej wymagania w ustawie o działalności pożytku publicznego i o wolontariacie w zakresie wspierania i upowszechniania kultury fizycznej. Wniosek taki można wysunąć na podstawie przepisów obowiązujących w ustawach o:

1. samorządzie gminnym, gdzie $\mathrm{w}$ art. 7 postanowiono, że do zadań własnych gminy należą sprawy kultury fizycznej i turystyki, w tym terenów rekreacyjnych i urządzeń sportowych, a także współpracy i działalności na rzecz organizacji pozarządowych oraz podmiotów wymienionych w art. 3 ust. 3 ustawy z dnia 24 kwietnia 2003 r. o działalności pożytku publicznego i o wolontariacie ${ }^{24}$;

2. samorządzie powiatowym, gdzie w art. 4 określono, że zadaniem publicznym powiatu o charakterze ponadgminnym jest kultura fizyczna i turystyka oraz współpraca i działalność na rzecz organizacji poza-

22 Tamże, s. 35.

23 K. Makowska, Finansowanie klubów sportowych na gruncie ustawy o partnerstwie publiczno-prywatnym, [w:] A. Babczuk, A. Talik (red.), Finansowanie sportu ze środków publicznych, Warszawa 2014, s. 108.

24 Ustawa z dnia 8 marca 1990 r. o samorządzie gminnym (tekst jedn. Dz.U. z 2016 r., poz. 446). 
rządowych oraz podmiotów wymienionych w art. 3 ust. 3 ustawy z dnia 24 kwietnia 2003 r. o działalności pożytku publicznego i o wolontariacie $\mathrm{e}^{25}$;

3. samorządzie województwa, gdzie w art. 14 samorząd województwa wykonuje zadania o charakterze wojewódzkim określone ustawami, w tym kultury fizycznej i turystyki ${ }^{26}$.

Warto pamiętać o tym, że art. 5 w związku z art. 3 ust. 2 i 3 u.o.d.p.p. nakłada na organy administracji publicznej obowiązek współpracy przy prowadzeniu działalności w sferze zadań publicznych z klubami sportowymi. Współpraca ta często przybiera formę wsparcia finansowego. Zlecenie realizacji zadań publicznych klubom sportowym wiąże się z udzieleniem dotacji celowej. W tym celu uchwala się program współpracy do 30 listopada roku poprzedzającego okres obowiązywania programu (art. 5a ust. 1 u.o.d.p.p.). Roczny program współpracy określa: cel główny i cele szczegółowe programu, zasady współpracy, zakres przedmiotowy, formy współpracy, priorytetowe zadania publiczne, okres realizacji programu, sposób realizacji programu, wysokość środków planowanych na realizację programu, sposób oceny realizacji programu, informację o sposobie tworzenia programu oraz o przebiegu konsultacji, tryb powoływania i zasady działania komisji konkursowych do opiniowania ofert w otwartych konkursach ofert (art. 5a ust. 4 pkt 1-11 u.o.d.p.p.).

Uzyskanie dotacji celowej przez kluby sportowe co do zasady odbywa się w ramach otwartego konkursu ofert (art. 11 ust. 2 u.o.d.p.p.). Oczywiście ustawa przewiduje także możliwość odstąpienia od formuły konkursu w przypadku zleceń o niskiej wartości i krótkim czasie realizacji (art. 19a u.o.d.p.p.). Należy jednak pamiętać, że cały proces organizowania i rozstrzygania konkursów mieści się w ramach przepisów art. 11-19a u.o.d.p.p. Określa się tam zasady konkursów, w tym informację o ogłoszeniu konkursu, sposobie jej rozpowszechniania czy wreszcie kryteria oceny ofert przez zainteresowane podmioty. Po rozstrzygnięciu otwartego

25 Ustawa z dnia 5 czerwca 1998 r. o samorządzie powiatowym (tekst jedn. Dz.U. z 2016 r., poz. 814).

26 Ustawa z dnia 5 czerwca 1998 r. o samorządzie województwa (tekst jedn. Dz.U. z 2016 r., poz. 486). 
konkursu ofert organ administracji publicznej bez zbędnej zwłoki zawiera umowę w sprawie wsparcia realizacji zadania publicznego lub powierzenia realizacji zadania publicznego, zobowiązując się w niej do przekazania klubowi sportowemu dotacji celowej na realizację zadania celowego objętego umową. Takich konkursów, w którym beneficjentami są kluby sportowe, jest bardzo wiele. Ponadto warto zasygnalizować, że kwoty udzielonego w ten sposób wsparcia są bardzo duże. Wystarczy prześledzić chociażby ostatnie dotacje udzielone przez jednostki samorządów terytorialnych, o których mowa poniżej.

W 2017 r. w gminie Piaseczno na zadanie publiczne w zakresie sportu przeznaczono $300.000 \mathrm{zt}^{27}$. Kwota ta została podzielona w różnej proporcji na trzy kluby sportowe. Z kolei w większej gminie Kalisz rozdysponowano na rok 2017 kwotę 4.080 .000 zł na kluby sportowe ${ }^{28}$. Kwoty w poszczególnych gminach bardzo się różnią. Wydaje się, że duże znaczenie przy otrzymywaniu środków ma wielkość budżetu i możliwości finansowe danej jednostki samorządu terytorialnego. Pewien wpływ ma także klasa rozgrywek, w której występuje dany klub sportowy.

\section{Studium interpretacji przepisów}

Interpretacja przepisów w przypadku udzielania dotacji dla klubów sportowych w ciągu kilku lat ewoluowała ${ }^{29}$. Należy przyjąć, że idzie ona w słusznym kierunku. Przyznanie dotacji celowej możliwe jest w oparciu o dwa modele finansowania dostępne w ustawie o sporcie oraz ustawie o działalności pożytku publicznego i o wolontariacie. Dlatego też warto w tym miejscu przytoczyć chociażby niektóre stanowiska regionalnych izb obrachunkowych czy orzeczeń sądów administracyjnych w powyższym zakresie.

W uchwale z dnia 22 stycznia 2013 r. Regionalna Izba Obrachunkowa w Warszawie w sprawie warunków finansowego wspierania przez

\footnotetext{
http://www.gosir-piaseczno.pl/dotacje-na-sport (dostęp: 01.04.2017 r.).

http://www.bip.kalisz.pl/ogloszenia/zadpubl/kom2401.pdf (dostęp: 01.04.2017 r.).

Na tle poprzednio obowiązującej ustawy o sporcie kwalifikowanym występowały duże utrudnienia i wątpliwości w tym zakresie.
} 
gminę klubów sportowych stwierdziła, że „zarówno przepis art. 27 ust. 2 ustawy o sporcie, jak też przepis art. 221 ust. 4 ustawy o finansach publicznych nie dają podstaw do nakładania warunków, które musi spełnić klub sportowy, aby otrzymać dotację celową. Warto zaznaczyć, że nie ma znaczenia, w jakiej formie działa klub sportowy oraz czy posiada licencję przyznaną przez właściwy polski związek sportowy, bowiem zgodnie $\mathrm{z}$ art. 28 ustawy o sporcie dotację może otrzymać tylko ten klub sportowy, który nie działa w celu osiągnięcia zysku”30.

Trzeba zasygnalizować, że jest to słuszna teza, gdyż organ jednostki samorządu terytorialnego nie powinien wykazywać kompetencji prawotwórczych w zakresie szerszym niż we wskazanej ustawie. Przepis art. 28 u.s. jasno precyzuje, jaki klub sportowy może starać się o dotację. Nie ma tam żadnego zapisu, aby posiadał on tzw. licencję przyznaną przez polski związek sportowy.

Z kolei w uchwale z dnia 15 grudnia 2010 r. Regionalna Izba Obrachunkowa w Zielonej Górze opowiedziała się za dwutorowością finansowania klubów sportowych. Izba wskazała, że „ustawodawca przewidział w ustawie o sporcie dwie możliwości finansowania zadania własnego jednostki samorządu terytorialnego z zakresu sportu, tj. podjęcie uchwały $\mathrm{z}$ art. 27 tej ustawy określającej odrębnie tryb finansowania zadania własnego w sferze sportu albo pozostanie przy dotychczasowych zasadach pożytku publicznego, stosując dyspozycję art. 28 ustawy” ${ }^{\text {"31. }}$

Niewątpliwie sprawy dotowania klubów sportowych rozstrzyga orzecznictwo sądów administracyjnych. Wojewódzki Sąd Administracyjny w Krakowie 16 kwietnia 2013 r. postanowił, że „w systemie prawnym finansów publicznych dotacje celowe dla klubów sportowych mogą być udzielane w dwóch trybach. Pierwszy tryb to dotacje udzielone na podstawie art. 11-19a ustawy o działalności pożytku publicznego i o wolontariacie, do których odsyła art. 221 ust. 1 i 2 ustawy o finansach publicznych. Wówczas dotacja przyznawana jest klubowi sportowemu realizującemu zadanie zlecone wspieranie i upowszechnianie kultury fizycznej. Udzielenie dotacji w tym trybie odbywa się po przeprowadzeniu otwarte- 
go konkursu ofert, chyba że szczególne przepisy tej ustawy przewidują inny tryb zlecenia. Drugi tryb opiera się na założeniu, że tworzenie warunków, w tym organizacyjnych sprzyjających rozwojowi sportu, stanowi zadanie własne jednostki samorządu terytorialnego, przy czym to na organie stanowiącym jednostki samorządu terytorialnego spoczywa obowiązek określenia w drodze uchwały, warunków i trybu finansowania tego zadania własnego ze wskazaniem w uchwale celu publicznego z zakresu sportu, który jednostka ta zamierza osiągnąć. Aby zastosować tryb udzielania dotacji celowych dla klubu sportowego w oparciu o art. 27 ust. 1 i 2 art. 27 ust. 1-3 ustawy o sporcie w związku z art. 221 ust. 4 ustawy o finansach publicznych, w pierwszej kolejności musi być podjęta uchwała w sprawie trybu postępowania o udzielenie dotacji na zadania z zakresu wspierania sportu inne niż określone w ustawie o działalności pożytku publicznego i o wolontariacie. Art. 28 ustawy o sporcie nie może stanowić samoistnej i wystarczającej podstawy do udzielenia dotacji dla klubów sportowych. Ustawodawca nakazuje w nim bowiem zastosowanie przepisów ustawy o finansach publicznych w zakresie udzielania dotacji celowych dla podmiotów niezaliczanych do sektora finansów publicznych i niedziałających w celu osiągnięcia zysku”32.

Od powyższego wyroku złożono skargę kasacyjną, którą oddalił Naczelny Sąd Administracyjny w wyroku z dnia 14 stycznia 2015 r., stanowiąc, iż „przyznanie dotacji dla klubu sportowego wymaga ustalenia celu publicznego z zakresu sportu w uchwale określającej warunki i tryb finansowania takiego zadania własnego i udzielenie tej dotacji, dla podmiotu, jeżeli nie jest dokonywane w drodze przepisów ustawy o działalności pożytku publicznego i o wolontariacie dokonuje się na podstawie umowy zawartej w oparciu o uchwałę określającą tryb udzielenia dotacji, sposób jej rozliczenia oraz kontroli wykonania takiego zadania. Zatem brak stosownych uchwał z zakresu warunków i trybu finansowania zadania własnego z zakresu sportu oraz określających tryb postępowania o udzielenie

32 Wyrok WSA w Krakowie z dnia 16 kwietnia 2013 r., I SA/Kr 84/13, Legalis nr 770184. 
dotacji jest przeszkodą prawną do podjęcia uchwały o udzielenie dotacji celowej klubowi sportowemu"33.

\section{Podsumowanie}

Idea dofinansowywania klubów sportowych z budżetu jednostek samorządu terytorialnego jest inicjatywą godną aprobaty. Przepisy prawne stwarzają organom stanowiącym jednostki samorządu terytorialnego ku temu możliwości. Wprowadzenie dwóch alternatywnych metod w zakresie finansowania klubów sportowych należy ocenić pozytywnie. Znaczenie klubów sportowych nawet tych najmniejszych przyczynia się do wzmocnienia ich społecznej roli. Bez odpowiednich środków byt tych klubów sportowych jest zagrożony. Ponadto kluby sportowe odgrywają istotną rolę w funkcjonowaniu gospodarki i realizacji zadań publicznych jednostek samorządu terytorialnego. Na tle powyższych rozważań jednoznacznie można stwierdzić, iż ustawodawca w sposób pełny stworzył możliwości prawne w kierunku dotowania klubów sportowych.

\section{Bibliografia:}

Cajsel W., Ustawa o sporcie. Komentarz, C.H. Beck, Warszawa 2011.

Chrzanowska P., Rola dotacji celowych z budżetu gminy w kontekście rozwoju klubów sportowych w małych miejscowościach, „Zeszyty Naukowe Politechniki Częstochowskiej Zarządzanie” 2015, nr 20, s. 17-25.

Dudek D., Pojęcie klubu sportowego, „Studia Humanistyczne” 2005, nr 5, s. 17-28.

Kosowski J., Finansowanie klubów sportowych na podstawie ustawy z 25.06.2010 r. o sporcie, „Samorząd Terytorialny” 2012, nr 7-8, s. 149-160.

Lachiewicz W., Uchwała o dotacjach z budżetu jednostki samorzqdu terytorialnego na cele publiczne z zakresu rozwoju sportu, [w:] P. Walczak (red.), Uchwały i zarzq̨dzenia organów samorzq̨du terytorialnego dotyczqce spraw finansowych, C.H. Beck, Warszawa 2016.

33 Wyrok NSA z dnia 14 stycznia 2015 r., II GSK 1941/13, Legalis nr 1199998. 
Makowska K., Finansowanie klubów sportowych na gruncie ustawy o partnerstwie publiczno-prywatnym, [w:] A. Babczuk, A. Talik (red.), Finansowanie sportu ze środków publicznych, C.H. Beck, Warszawa 2014.

Obrębalski M., Wspieranie rozwoju sportu jako zadanie jednostek samorzqdu terytorialnego, [w:] A. Babczuk, A. Talik (red.), Finansowanie sportu ze środków publicznych, C.H. Beck, Warszawa 2014.

Rejman A., Uczniowskie kluby sportowe w Polsce w świetle obowiqzujących uregulowań prawnych oraz orzecznictwa sq̨dów powszechnych, „Quality In Sport” 2015, nr 4, s. 54-62.

Sawicka K., Podstawy prawne finansowania sportu z budżetu jednostek samorzqdu terytorialnego, [w:] A. Babczuk, A. Talik (red.), Finansowanie sportu ze środków publicznych, C.H. Beck, Warszawa 2014.

Wankiewicz B., Wpływ sportu na rozwój lokalny w świetle ustawy o sporcie, „Zeszyty Naukowe Uniwersytetu Szczecińskiego” 2011, nr 690, s. 413-427. 